\title{
NOTE
}

\section{The ultimate opportunists: consumers of seston}

\author{
Rafel Coma ${ }^{1, *}$, Marta Ribes $^{2}{ }^{\text {, Josep-Maria Gili }}{ }^{3}$, Roger N. Hughes ${ }^{4}$ \\ ${ }^{1}$ Centre d'Estudis Avançats de Blanes (CEAB-CSIC), Camí de Sta. Bàrbara s/n, 17300 Blanes, Girona, Spain \\ ${ }^{2}$ Hawaii Institute of Marine Biology, University of Hawaii, PO Box 1346, Coconut Island, Kaneohe 96744, Hawaii, USA \\ ${ }^{3}$ Institut de Ciències del Mar, CNIMA-CSIC, Ps. Marítim 37-49, 08003 Barcelona, Spain \\ ${ }^{4}$ School of Biological Sciences, University of Wales, Bangor, Gwynedd LL57 2UW, Wales, United Kingdom
}

\begin{abstract}
The seston represents a highly dilute food source to potential consumers. Consequently, 3 general properties may be expected of sessile filter feeders: (1) high retention efficiency; (2) possession of a low-energy pump system in active filter feeders; and (3) consumption of seston fractions in proportion to availability (i.e. opportunistic feeding). Whereas the first 2 properties have been well documented, until recently little evidence had been adduced for the third. We assessed whether a pattern across particular studies exists that could provide evidence of opportunistic feeding. Recent studies of the seasonal variation of seston composition and of natural feeding of species representing 3 contrasting feeding modes were reviewed. For the first time, it was possible to demonstrate in the field that sessile filter feeders consume a broad spectrum of seston fractions in proportion to their availability. We conclude that such opportunistic feeding, within phylogenetically determined broad limits, is a general property of sessile filter feeders, appropriate for exploiting the ubiquitous but dilute and dynamic seston.
\end{abstract}

KEY WORDS: Filter feeders $\cdot$ Feeding $\cdot$ Natural diet $\cdot$ Seston $\cdot$ Benthic communities

Resale or republication not permitted without written consent of the publisher

Energy enters marine systems by way of primary producers. They and the products of their activity make up the largest food source in the oceans: the seston. Representing total particulate matter suspended in the water column, the seston consists of an enormous variety of substances, including detrital particulate organic matter, planktonic animals and plants, which are all dynamically linked by the microbial food web (Azam et al. 1983). Despite its variety and ubiquity, however, the seston represents a highly dilute food source to potential consumers (Riisgård \& Larsen 1996) such as the sessile filter-feeding animals that typically dominate benthic communities (Officer et al. 1982, Gili \& Coma

*E-mail: coma@icm.csic.es
1998). Consequently, 3 general properties may be expected of sessile filter feeders: (1) efficient filtration, i.e. high retention efficiency of particles within a sizerange governed by the filtering mechanism (LaBarbera 1984, Okamura 1990, Vogel 1994); (2) possession in active filter feeders of a low-energy pump system capable of running continuously (Riisgård \& Larsen 1996); and (3) consumption of seston fractions in proportion to their availability (Hughes 1980).

Six feeding modes have been recognised in actively filter-feeding benthic animals: collar sieving in sponges, cirri trapping in bivalves, ciliary sieving in bryozoans, ciliary downstream collecting in different taxonomic groups, mucus-net filter feeding, e.g. in ascidians and ciliary upstream collection, e.g. in phoronids (see Riisgård \& Larsen 2001 for a review). Although in the field many factors may influence retention efficiency (Wotton 1990), under non-extreme conditions this usually exceeds $80 \%$ and often approaches $100 \%$ for a spectrum of particle sizes determined by the feeding mode (Jørgensen et al. 1984, LaBarbera 1984, Okamura 1990, Vogel 1994).

The energetic cost of active filter feeding, expressed as power output of the pump relative to total respiratory energy loss, amounts to less than $4 \%$ for the different groups examined (see Riisgård \& Larsen 2001 for a review). Indeed, there is no equivalent cost for passive filter feeders, since they do not possess a pump. Passive suspension feeders depend upon supplied food reaching their organs of capture. Sieving and direct interception have been identified as the main mechanisms of particle capture in passive suspension feeders (Patterson 1991, Sebens et al. 1996, Ribes et al. 1999b). Whereas the above properties of (1) and (2) have been well documented (Okamura 1990, Gili \& Coma 1998), only recently has substantial evidence been adduced for (3). Our purpose here is to review this evidence. 
Development of an in situ technique using incubation jars, together with the improvement of methods for analysing the seston fractions consumed, has enabled continuous dietary records to be made for filter feeders in their natural habitat (Ribes et al. 1998a,b, 1999a,b, 2000). Because the submersible apparatus is surface-independent, it allows us to assess oxygen concentration changes and feeding rates over prolonged periods. Two submerged jars, one containing the experimental organism, the other a control, are manipulated by SCUBA divers. Particle concentration is measured in water samples taken from the jars at fixed time intervals (clearance method, Riisgård 2001). Feeding rates on specific seston fractions are calculated by comparing rates of change in concentration of these fractions between control and experimental jars (Ribes et al. 1998a,b, 1999a,b, 2000).

Variations in seasonal abundance and composition of microbial planktonic communities (free-living bacteria, hereafter bacteria, and protozoans), phytoplankton (diatoms and dinoflagellates), DOC and detrital POC were examined in a near-bottom littoral ecosystem in the Medes Islands, Spain (northwestern Mediterranean) over an entire year. Mean DOC and detrital POC values over the year were $2560 \pm$

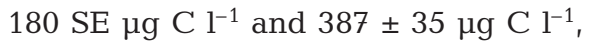
respectively. Detrital organic carbon was always the main POC fraction present and bacteria (including heterotrophic bacteria, Synechococcus sp. and Prochlorococcus sp.) were the main contributors to the live carbon fraction (bacteria: $41 \pm 5 \%, 5.5 \pm 0.04 \times 10^{5}$ cells $\mathrm{ml}^{-1}, 8.8 \pm 0.05 \mu \mathrm{g} \mathrm{Cl} \mathrm{l}^{-1}$, Fig. 1a). At the same location, simultaneous studies were made of the natural diets of 3 types of filter feeder. None of the species ingested any significant amount of DOC. A colony of the sponge Dysidea avara (biomass: $0.2 \mathrm{~g}$ AFDW) ingested $175 \pm 35 \mu \mathrm{g} \mathrm{C} \mathrm{g} \mathrm{AFDW}{ }^{-1} \mathrm{~h}^{-1}$ annually. Overall, bacteria contributed $74 \pm 14 \%$ of the total ingested carbon, pico- and nanoflagellates contributed $11 \pm 3 \%$ and phytoplankton contributed $11 \pm$ $10 \%$. Thus, $85 \%$ of the carbon ingested by $D$. avara was obtained from the frac- tion smaller than $5 \mu \mathrm{m}$, with the fraction larger than $5 \mu \mathrm{m}$ contributing only $15 \%$. However, contributions by the different fractions varied over the year (Fig. 1b). Annual mean ingestion by the ascidian Halocynthia

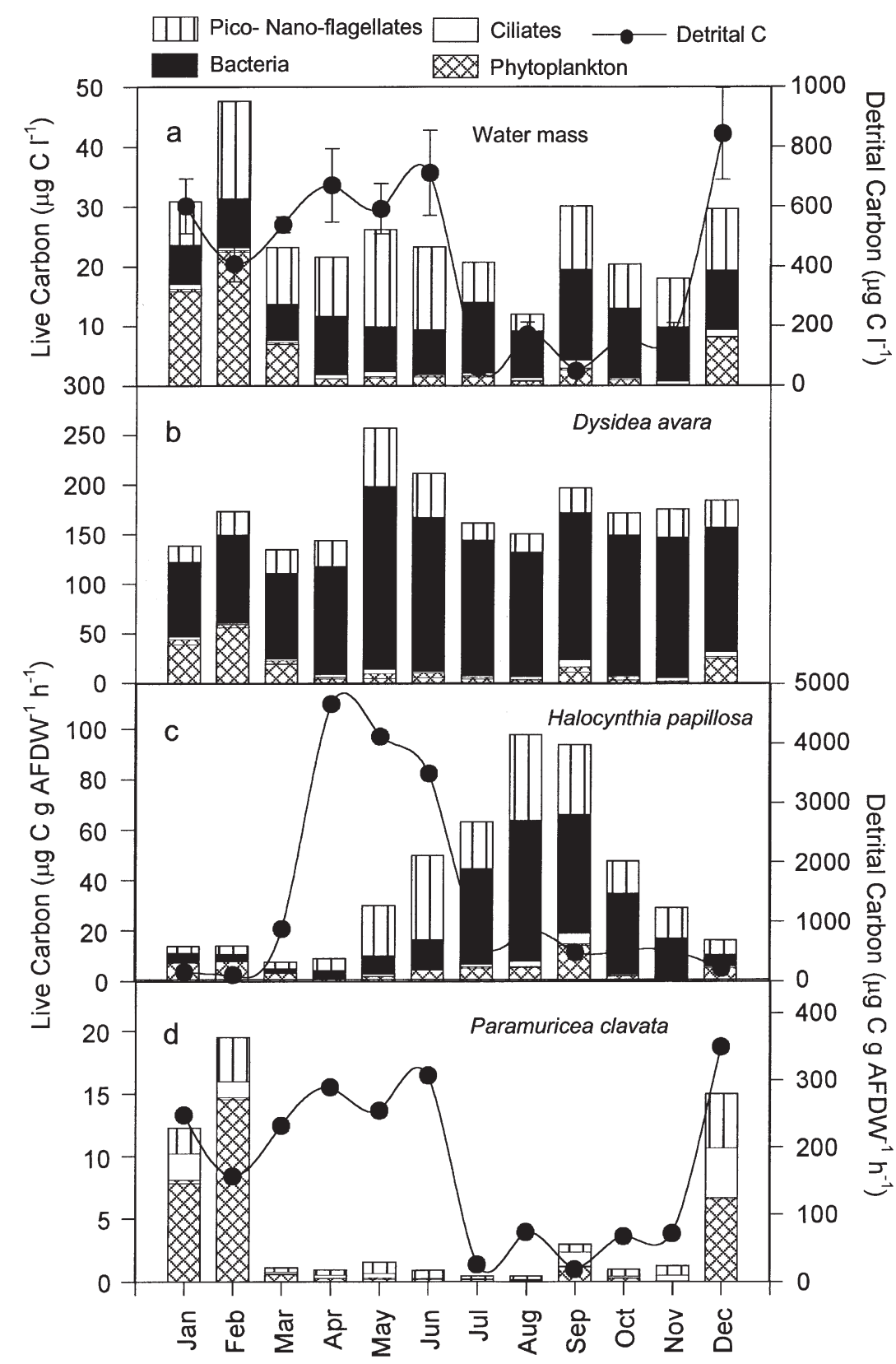

Fig. 1. (a) Variations in seasonal abundance and composition of microbial planktonic communities (bacteria and protozoans), phytoplankton (diatoms and dinoflagellates), and detrital POC were examined in a near-bottom littoral ecosystem in the Medes Islands, Spain (northwestern Mediterranean) over an entire year. (b) Monthly estimates of total organic carbon ingested throughout an annual cycle by a colony of the sponge Dysidea avara (biomass: $0.2 \mathrm{~g}$ AFDW). (c) Monthly estimates of total organic carbon ingested throughout an annual cycle by the ascidian Halocynthia papillosa (biomass: $0.25 \mathrm{~g}$ AFDW). (d) Monthly estimates of organic carbon $<100 \mu \mathrm{m}$ ingested throughout an annual cycle by the gorgonian Paramuricea clavata (biomass: $1.07 \mathrm{~g}$ AFDW). Data from Ribes et al. 1998a,1999a,b,c 
papillosa (biomass: $0.25 \mathrm{~g}$ AFDW) was $1305 \pm 496 \mu \mathrm{g} \mathrm{C}$ g AFDW ${ }^{-1} \mathrm{~h}^{-1}$. Carbon of detrital origin accounted for $92 \pm 2 \%$ of the total ingested carbon and displayed a marked seasonal pattern. Ingestion of live carbon accounted for $8 \pm 2 \%$ of the total and the highest values were recorded in summer and autumn (70 \pm 14 and $57 \pm 19 \mu \mathrm{g} \mathrm{C} \mathrm{g} \mathrm{AFDW}{ }^{-1} \mathrm{~h}^{-1}$, respectively), with bacteria accounting for about $45 \%$ of the total live carbon ingested. In winter, phytoplankton accounted for over half of the total live carbon ingested, and in spring flagellates accounted for $50 \%$ of the total live carbon ingested (Fig. 1c). A colony of the gorgonian Paramuricea clavata (biomass: $1.07 \mathrm{~g}$ AFDW) ingested $179 \pm$ $10 \mu \mathrm{g} \mathrm{C} \mathrm{g} \mathrm{AFDW}^{-1} \mathrm{~h}^{-1}$ annually representing particles $<100 \mu \mathrm{m}$ and comprised of nanoflagellates, phytoplankton, ciliates, and detrital POC depending on the season (Fig. 1d). Detrital carbon accounted for $96 \pm 5 \%$ of the total ingested carbon $<100 \mu \mathrm{m}$ but exhibited a marked seasonal pattern (high values in winter and spring). P. clavata also consumes zooplankton (Coma et al. 1994). The contribution of zooplankton to the total ingestion was similar to that of detritus (about $48 \%$ each), while live carbon $<100 \mu \mathrm{m}$ accounted for about $4 \%$ of the total ingestion (Ribes et al. 1999b).

From the above data, it is clear that diets associated with the different feeding modes were each characterised by a persistently dominant fraction of the seston. The sponge Dysidea avara fed predominantly on bacteria. The ascidian Halocynthia papillosa fed predominantly on detritus. The gorgonian Paramuricea clavata fed predominantly on detritus and zooplankton. These results are consistent with the size spectrum of efficient filtration reported for sponges and ascidians (Randøv \& Riisgård 1979, Jørgensen et al. 1984, Ribes et al. 1998a, 1999a). The retention spectrum of passive filter feeding in gorgonians ranges from $3.8 \mu \mathrm{m}$ (nanoeukaryotes) to large seston particles several hundred microns in diameter, such as detrital particles and zooplankton (Coma et al. 1994, Ribes et al. 1998b, 1999b). The relative abundance of the different fractions consumed paralleled seasonal changes in availability (Fig. 1). These field studies therefore have shown, for the first time, that sessile filter feeders consume a broad spectrum of seston fractions in proportion to their abundance in the water column, signifying opportunistic feeding.

Of course, if phylogenetic characteristics of the filter and pump system generate different dietary signatures, opportunistic feeding will not result in the indiscriminate capture of particles across the entire range. For example, the absence of detrital particles in the diet of Dysidea avara appeared attributable to their relatively large size, which was associated with their principal origin from fragmenting macroalgae, and placed them beyond the scope of the collar-sieving mechanism (Ribes et al. 1999a). On the other hand, the large size of these detrital particles explained the observed importance of detritus in the diet of Paramuricea clavata, whose tentacular system readily handles such particles. Furthermore, despite being a minor component of the seston, ciliates comprised a significant fraction of the live-carbon diet of $P$. clavata, whose nematocysts are particularly efficient at capturing live prey. Thus, consumption in proportion to availability must be expected only within the spectrum of seston fractions appropriate to each filtering mechanism.

Care should be taken when invoking phylogenetic constraints, however, since the mussel Mytilus edulis, traditionally regarded as a microphagous filter feeder, has now been shown to be an important consumer of macrozooplankton (Davenport et al. 2000). We conclude that opportunistic feeding within phylogenetically determined broad limits is a general property of sessile filter feeders, appropriate for exploiting the ubiquitous but dilute and dynamic seston.

Acknowledgements. This work was improved by the comments of 4 reviewers. Support for this work was provided by a RED research contract from the 'Generalitat de Catalunya' to R.C., a postdoctoral fellowship from the 'Ministerio de Educación y Cultura' to M.R. and a DGICYT grant PB98-0496C03-01.

\section{LITERATURE CITED}

Azam FT, Fenchel JG, Field JS, Gray LA, Meyer-Reil Thinstad F (1983) The ecological role of water-column microbes in the sea. Mar Ecol Prog Ser 10:257-263

Coma R, Gili JM, Zabala M, Riera T (1994) Feeding and prey capture cycles in the aposymbiotic gorgonian Paramuricea clavata. Mar Ecol Prog Ser 155:257-270

Davenport J, Smith RJJ, Packer M (2000) Mussels Mytilus edulis: significant consumers and destroyers of mesozooplankton. Mar Ecol Prog Ser 198:131-137

Gili JM, Coma R (1998) Benthic suspension feeders: their paramount role in littoral marine food webs. Trends Ecol Evol 13:316-321

Hughes RN (1980) Optimal foraging theory in the marine context. Oceanogr Mar Biol 18:423-481

Jørgensen CB, Kiørboe T, Møhlenberg F, Riisgård HU (1984) Ciliary and mucus-net filter feeding, with special reference to fluid mechanical characteristics. Mar Ecol Prog Ser 15:283-292

LaBarbera M (1984) Feeding currents and particle capture mechanisms in suspension feeding animals. Am Zool 24:71-84

Officer CB, Smayda TJ, Mann R (1982) Benthic filter feeding: a natural eutrophication control. Mar Ecol Prog Ser 9: 203-210

Okamura B (1990) Behavioural plasticity in the suspension feeding of benthic animals. In: Hughes RN (ed) Behavioural mechanisms of food selection. Springer-Verlag, Berlin, p 637-660

Patterson MR (1991) The effects of flow on polyp-level prey 
capture in an octocoral, Alcyonium sidereum. Biol Bull 180:93-102

Randøv A, Riisgård HU (1979) Efficiency of particle retention and filtration rate in four species of ascidians. Mar Ecol Prog Ser 1:55-59

Ribes M, Coma R, Gili JM (1998a) Seasonal variation of in situ feeding rates by the temperate ascidian Halocynthia papillosa. Mar Ecol Prog Ser 175:201-213

Ribes M, Coma R, Gili JM (1998b) Heterotrophic feeding by gorgonian corals with symbiotic zooxanthellae. Limnol Oceanogr 43:1170-1179

Ribes M, Coma R, Gili JM (1999a) Natural diet and grazing rate of the temperate sponge Dysidea avara (Demospongiae, Dendroceratida) throughout an annual cycle. Mar Ecol Prog Ser 176:179-190

Ribes M, Coma R, Gili JM (1999b) Heterogeneous feeding in benthic suspension feeders: the natural diet and grazing rate of the temperate gorgonian Paramuricea clavata (Cnidaria: Octocorallia) over a year cycle. Mar Ecol Prog Ser 183:125-137

Ribes M, Coma R, Gili JM (1999c) Seasonal variation of particulate organic carbon, dissolved organic carbon and the contribution of microbial communities to the live particulate organic carbon in a shallow near-bottom ecosystem at

Editorial responsibility: Otto Kinne (Editor),

Oldendorf/Luhe, Germany the Northwestern Mediterranean sea. J Plankton Res 21: 1077-1100

Ribes M, Coma R, Gili JM, Svoboda A, Julia A, Parera J (2000) An improved 'semi-closed' recirculating system for the in situ study of feeding and respiration of benthic suspension feeders. Sci Mar 64:265-275

Riisgård HU (2001) On measurement of filtration rates in bivalves - the stony road to reliable data: review and interpretation. Mar Ecol Prog Ser 211:275-291

Riisgård HU, Larsen PS (1996) Filter-feeding in marine macro-invertebrates: pump characteristics, modelling and energy cost. Biol Rev 70:67-106

Riisgård HU, Larsen PS (2001) Comparative ecophysiology of active zoobenthic filter-feeding, essence of current knowledge. J Sea Res 44:169-193

Sebens KP, Vandersall KS, Savina LA, Graham KR (1996) Zooplankton capture by two scleractinian corals, Madracis mirabilis and Monastrea cavernosa, in a field enclosure. Mar Biol 127:303-317

Vogel S (1994) Life in moving fluids. The physical biology of flow. Princeton University Press, Princeton

Wotton RS (1990) Methods for capturing particles in benthic animals. In: Wotton RS (ed) The biology of particles in aquatic systems. CRC Press, Boca Raton, p 161-181

Submitted: November 10, 2000; Accepted: June 12, 2001

Proofs received from author(s): July 31, 2001 